\title{
Antibacterial Activity of Citrus Aurantifolia Leaves Extracts Against Some Enteric Bacteria of Public Health Importance
}

\author{
Abubakar U Zage ${ }^{1}$, Sani Tajo $\mathrm{T}^{2}$ and Muhammad Ali ${ }^{3 *}$ \\ ${ }^{1}$ Department of Microbiology, Kano State University of Science and Technology Wudil Kano, Nigeria \\ ${ }^{2}$ Department of Environmental Health, School of Hygiene, Nigeria \\ ${ }^{3}$ Department of Microbiology, Federal University Gusau, Nigeria
}

*Corresponding author: Muhammad Ali, Department of Microbiology, Federal University Gusau, Nigeria

\begin{abstract}
The study was conducted to determine the phytochemical composition and antibacterial activity of Citrus aurantifolia leaves extracts against clinical isolates of some enteric bacteria of public health importance. The result of phytochemical screening of the leaves extracts shows the presence of alkaloid, glycoside, saponin, tannin, flavonoid, steroids, terpenoid and phenol. The result of antibacterial efficacy of the extracts against the isolates indicated that the extracts were active against the isolates with higher activity in ethanol extract (with average zone of inhibition of $14.91 \mathrm{~mm}$ ) when compared to aqueous extract $(12.67 \mathrm{~mm})$. The result of susceptibility of the isolates to the extracts showed Shigella was more sensitive to the extract with average zone of inhibition of $14.90 \mathrm{~mm}$, followed by Klebsiella $(14.49 \mathrm{~mm})$, Escherichia coli $(13.77 \mathrm{~mm})$ and Salmonella typhi with average zone of inhibition of $12.01 \mathrm{~mm}$. The minimum inhibitory concentration (MIC) of the extracts showed that dilutions of various concentrations of aqueous and ethanol of leaves extracts can inhibit the growth or kill the isolates at a concentration of between $2.125-20 \mathrm{mg} / \mathrm{ml}$. Statistical analysis of the results indicated that there is no significant different in the activity of the extracts against the isolates used at $\mathrm{p}<0.05$. Findings from this study support the use of Citrus aurantifolia leaves extracts for medicinal purposes.
\end{abstract}

Keywords: Antibacterial activity; Citrus aurantifolia; Phytochemical; Enteric bacteria extract

\section{Introduction}

Natural products such as plants have been integral part traditional medicine system in ancient such as Chinese, Ayurvedic and Egyptian [1]. Several published reports had described the antimicrobial activity of various crude extracts of plants either in single or in combination [2]. It has been estimated that about 2.5 million species of higher plants and their therapeutic values are yet to be determined. However, herbal extracts are becoming popular as natural medicine; preservatives and additives [3]. According to World Health Organization [4] medicinal plants contain substances in one of its organs such as stem, root, leaves, rhizomes, fruits, flower and seeds that can be used for therapeutic purposes or which are precursor for chemo-pharmaceutical semi-synthesis [4]. The medicinal plants are employed in the treatment or control of disease condition due to the presence of biochemical components called phytochemical [5]. Phytochemicals are considered as bioactive substances of plant origin and are of medical importance. They are otherwise known as secondary metabolites as they are of little important to the plant who manufactured them. These secondary metabolites synthesized naturally in various organs of plants such as leaves, stem, root, flower and seed [6]. Most of the modern drugs used today were originally obtained from plants [7]. Many researches confirmed the herbal extract boost immune system by stimulating the production of white blood cell which fight diseases [8]. Citrus aurantifolia belongs to Rutaceae, it is a polyembroyonic plant cultivated in several part of the world especially hot subtropical or tropical region such as India, USA, Nigeria, Mexico, 
West indies and Egypt [9]. The plant is shrub in nature and height of about 2 meter tall, evergreen with dense and irregular branches which possess short and stiff spines. The Citrus aurantifolia fruits are ovoid berry of about $3-6 \mathrm{~cm}$ in diameter and sometimes possess apical papilla. When ripe, the fruits turn yellow from initial blue [10]. The plant is used in traditional medicine for treatment of several diseases such as cold and stomach ailment. It can also be used as an antiseptic, mosquito repellant, antifungal, antibacterial and antiviral agent. The health benefits of Citrus aurantifolia plant are highly associated with the high amount of bioactive constituents it contained such as phenols, flavonoids, carotenoid, vitamins and minerals [11]. Limes contain unique flavonoid compounds that have antioxidant and anti-cancer properties. The flavonoids help to inhibit cell division in many cancer cell lines in addition to its antimicrobial efficacy [12]. The plant also demonstrated bioactive activities for cold, fever, sinusitis, sore throats, asthma and bronchitis [13]. Antibacterial assessment of Citrus aurantifolia aqueous ethanol, acetone, chloroform, ethanol and petroleum ether leaves extract conducted by Pathan R et al. [14] against various pathogen showed significant activity against Staphylococcus aureus, Pseudomonas spp, Klebsiella pneumonia along with antifungal activity against Mucor spp., Aspergillus fumigates and Aspergillus niger. Kandpal et al. [15] isolated actinomycetes from C. aurantifolia and tested its antibacterial efficacy against different pathogen. In this study, five actinomycetes isolated from the plant exhibited antibacterial activity against various pathogens including $S$. aureus, E. coli, K. Pneumonia and S. typhi. The present study was aimed at determining the phytochemical constituent and antibacterial activity of Citrus aurantifolia leaves extracts against clinical isolates of some enteric bacteria.

\section{Materials and Methods}

\section{Collection, identification and authentication of plant materials}

The leaves of C. aurantifolia were used in this study. The leaves were collected from the botanical garden of School of Technology, Kano State Polytechnic. After collection, the leaves were identified and authenticated at the herbarium in the Department of Plants Science, Bayero University Kano with the following voucher number BUKHAN 0341, voucher specimen of the plant's leaves were deposited in the herbarium for future references. The leaves were then rinsed with distilled water and air dried at room temperature for 2 weeks. The dried leaves were made into fine powder under laboratory condition using sterile pestle and mortar. The powder was stored in dark and air tight container.

\section{Test organisms}

Five (4) enteric bacterial isolates recovered from stool of infected patients attending Murtala Muhammad General Hospital, Kano namely; Escherichia coli, Salmonella typhi, Klebsiella pneumoniae and Shigella were obtained from Microbiology Laboratory of Kano University of Science and Technology Wudil, Kano. The bacterial isolates were characterized to species level using various laboratory procedures which include Gram's stain, cultural characterization and Biochemical tests include (Indole, Methyl red, Voges Proskauer, Catalase, Citrate utilization and coagulase tests) as described by Holt et al. [16] and Cheesbrough [17]. The isolates were maintained on Nutrient agar slants at $4{ }^{\circ} \mathrm{C}$.

\section{Indole test}

Indole test was conducted according to Cheesbrough [17] using Tryptophan broth. The broth was inoculated with the isolate of the test organism, and then incubated at $37{ }^{\circ} \mathrm{C}$ for 24 . About $0.5 \mathrm{ml}$ of Kovack's reagents was added to the broth culture.

\section{Methyl red test}

Indole test was conducted using MR-VP broth as described by Holt et al. [16] and Cheesbrough [17]. The MR-VP broth was inoculated with an isolate of the test organism with the aid of sterile inoculating wire loop. The inoculated broth was incubated at $37^{\circ} \mathrm{C}$ for 24 hours. About 5 drops of Methyl-red reagent was added to the broth culture.

\section{Voges proskauer}

MR-VP broth was inoculated with an isolate of the test organism using sterile inoculating loop and incubated at $37^{\circ} \mathrm{C}$ for 24 hours. Six milliliter $(6 \mathrm{ml})$ of $5 \%$ alpha naphthol was added followed by $0.2 \mathrm{ml}$ of $\mathrm{KOH}$. The tube was shaken gently and remained undisturbed for 5 minutes.

\section{Citrate utilization test}

Simmon's citrate agar was streaked back and forth with inoculums of the test organism and incubated aerobically at $37{ }^{\circ} \mathrm{C}$ for 24 hours.

\section{Preparation of the leaves extracts}

Water and ethanol were used as solvent for extraction. The aqueous and ethanol extracts of the plant leaves were prepared separately. Fifty grams (50g) of leaves powder was prepared by mixing with $500 \mathrm{ml}$ each of distilled water and ethanol respectively in 1liter flask. The flask were kept were kept for 3 day with intermittent shaking at room temperature. Filtration of the mixture was conducted using Whatman filter paper. The ethanol filtrate was evaporated using rotary evaporator at $50{ }^{\circ} \mathrm{C}$ while the aqueous filtrate was evaporated at $40{ }^{\circ} \mathrm{C}$ in water bath until dried extract samples were obtained. All the dried extract samples were dissolved in $10 \%$ DMSO separately to the final concentration of $200 \mathrm{mg} / \mathrm{ml}$ as a stock concentration. The prepared extracts were refrigerated for further use [18]. 


\section{Qualitative phytochemical screening}

The preliminary phytochemical screening of C. aurantifolia leaves extracts was conducted using standard laboratory methods as described by Sofowora [19] and Trease and Evans [20]. The presence of bioactive constituents such as alkaloids, reducing sugars, steroid, glycoside, phenol, Anthraquinones, terpenoids, flavonoids, saponin and tannin were determined.

\section{Antibacterial assay of the extracts}

Agar well diffusion method was used to determine the activity of the extracts against the test isolates as adopted by Nas et al. [21] with little modification. A bacterial suspension equivalent to 0.5 McFarland Standard $\left(1.5 \times 10^{6} \mathrm{CFU}\right)$ was introduced onto the surface of freshly prepared Mueller- Hinton agar medium in a sterile Petri-dish. Using $6 \mathrm{~mm}$ diameter sterile cork borer, 5 wells were constructed in the agar medium at equidistance. The agar well were filled with $0.1 \mathrm{ml}$ of the extracts at concentration of $100,75,50$ and $25 \mathrm{mg} / \mathrm{ml}$. the fifth well was filled with $0.1 \mathrm{ml}$ of $50 \mathrm{mg} / \mathrm{ml}$ Amoxicillin (Micro Lab Limited) as positive control for the experiment. The plates stand for about 1 hour until proper diffusion of the extracts into the medium was done. The plates were incubated at $37{ }^{\circ} \mathrm{C}$ for 24 hours, and thereafter the plates were observed for zones of inhibition and measured. Each experiment was conducted in triplicate and the average values of zone of inhibition were recorded.

\section{Determination of minimum inhibitory concentration (MIC)}

Broth dilution method was used for MIC determination. During the process, double fold serial dilution of the extracts was prepared in Nutrient broth by adding $2 \mathrm{ml}$ of $100 \mathrm{mg} / \mathrm{ml}$ of the extract into a test tube, thus producing solution containing 50mg/ $\mathrm{ml}$ of the extract. The process of serial dilution continues until a concentration of $25,12.5,6.25,3.125 \mathrm{mg} / \mathrm{ml}$ were obtained. The test tube Number 6 does not contain extract and served as negative control for the experiment. About $0.5 \mathrm{ml}$ of the standard organism (0.5 McFarland equivalents) was inoculated into each test tube containing the extracts and incubated at $37^{\circ} \mathrm{C}$ for 24 hours. The test tubes were observed for bacterial growth by checking the presence of turbidity [21].

\section{Antibacterial activity of aqueous extract}

Table 2: Antibacterial activity of C. aurantifolia leaves aqueous extract.

\begin{tabular}{|c|c|c|c|c|c|}
\hline Isolates & 25 & 50 & 75 & 100 & Control \\
\hline Salmonella typhi & $08.67 \pm 0.00^{\mathrm{a}}$ & $09.84 \pm 0.12^{\mathrm{a}}$ & $10.34 \pm 0.31^{\mathrm{a}}$ & $13.18 \pm 0.22^{\mathrm{a}}$ & 19.34 \\
\hline Escherichia coli & $08.44 \pm 0.25^{\mathrm{a}}$ & $12.40 \pm 0.34^{\mathrm{a}}$ & $13.70 \pm 0.29^{\mathrm{a}}$ & $16.41 \pm 0.19^{\mathrm{b}}$ & 18.67 \\
\hline Klebsiella pneumoneae & $10.40 \pm 0.27^{\mathrm{a}}$ & $11.28 \pm 0.29^{a}$ & $13.62 \pm 0.19^{b}$ & $15.21 \pm 0.45^{b}$ & 19.67 \\
\hline Shigella sp & $11.83 \pm 0.21^{\mathrm{a}}$ & $12.43 \pm 0.18^{\mathrm{a}}$ & $16.78 \pm 0.22^{b}$ & $18.23 \pm 0.33^{\mathrm{b}}$ & 20.34 \\
\hline
\end{tabular}

Key: Values having different superscript on the same row are considered significantly different at $\mathrm{p}<0.05$. 
The result of antibacterial activity of aqueous leaf extract of $\mathrm{C}$. aurantifolia is presented in Table 2. According to the result, the zone of inhibition recorded by the isolates depends on the concentration of the extract and the types of bacteria isolate. Shigella has the highest zone of inhibition $(18.23 \pm 0.36 \mathrm{~mm})$ at $100 \mathrm{mg} / \mathrm{ml}$. The zone of inhibition of the control (Amoxicillin $50 \mathrm{mg} / \mathrm{ml}$ ) ranges from to $19.34-20.34 \mathrm{~mm}$

\section{Antibacterial activity of ethanol extract}

The result of antibacterial activity of ethanol leaf extract of $C$. aurantifolia is presented in Table 3. According to the result, the zone of inhibition recorded by the isolates depends on the concentration of the extract and the types of bacteria isolate. Klebsiella pneumoniae has the highest zone of inhibition $(19.27 \pm 0.31 \mathrm{~mm})$ at $100 \mathrm{mg} / \mathrm{ml}$. The zone of inhibition of the control (Amoxicillin $50 \mathrm{mg} / \mathrm{ml}$ ) ranges from to $19.34-20.34 \mathrm{~mm}$.

Table 3: Antibacterial activity of C. aurantifolia leaves aqueous extract.

\begin{tabular}{|c|c|c|c|c|c|}
\hline Isolates & 25 & 50 & 75 & 100 & Control \\
\hline Salmonella typhi & $11.25 \pm 0.28^{\mathrm{a}}$ & $12.85 \pm 0.18^{\mathrm{a}}$ & $14.33 \pm 0.36^{\mathrm{a}}$ & $15.59 \pm 0.21^{\mathrm{b}}$ & 19.34 \\
\hline Escherichia coli & $12.33 \pm 0.19^{\mathrm{a}}$ & $13.00 \pm 0.10^{\mathrm{b}}$ & $15.96 \pm 0.24^{\mathrm{b}}$ & $17.89 \pm 0.35^{\mathrm{b}}$ & 18.67 \\
\hline Klebsiella pneumoneae & $12.32 \pm 0.12^{\mathrm{a}}$ & $16.15 \pm 0.22^{\mathrm{a}}$ & $17.69 \pm 0.28^{\mathrm{b}}$ & $19.27 \pm 0.31^{\mathrm{b}}$ & 19.67 \\
\hline Shigella sp & $12.76 \pm 0.22^{\mathrm{a}}$ & $14.90 \pm 0.28^{b}$ & $15.67 \pm 0.19^{b}$ & $16.60 \pm 0.22^{\mathrm{b}}$ & 20.34 \\
\hline
\end{tabular}

Key: Values having different superscript on the same row are considered significantly different at $p<0.05$

\section{MIC and MBC of the extract}

Table 4 presents the minimum inhibitory concentration and minimum bactericidal concentration of aqueous and ethanol extract of $C$. aurantifolia leaves. According to the result, various concentrations of the extracts were able to inhibit or kill the isolates. Lower MIC $(3.125 \mathrm{mg} / \mathrm{ml})$ was shown by ethanol extract than aqueous extract. The ethanol extract exhibit MBC of between $12.5-50 \mathrm{mg} / \mathrm{ml}$.

Table 4: Minimum inhibitory concentration (MIC) and MBC of the extracts.

\begin{tabular}{|c|c|c|c|c|}
\hline \multirow{2}{*}{ Isolates } & MIC & MBC & \multirow{2}{*}{ MIC (mg/ml) } & MBC (mg/ml) \\
\cline { 2 - 5 } & $\mathbf{( m g / \mathbf { m l } )}$ & $\mathbf{( m g / \mathbf { m l } )}$ & 6.25 & 25 \\
\hline Salmonella typhi & 25 & 50 & 6.25 & 25 \\
\hline Escherichia coli & 6.25 & 12.5 & 6.25 & 50 \\
\hline Klebsiella pneumoneae & 12.5 & 50 & 3.125 & 12.5 \\
\hline Shigella sp & 6.25 & 25 & & 25 \\
\hline
\end{tabular}

\section{Discussion}

Phytochemical screening of aqueous and ethanol leaves extracts of Citrus aurantifolia indicate the presence of alkaloid, flavonoid, glycoside, saponin, steroid, phenols, terpenoid and tannin. The presence of such secondary metabolites in plant parts was responsible for its antibacterial efficacy. The saponin and tannin are known to possess antimicrobial activities, and as result, the tannin play an important role in wound healing [22-24]. The alkaloid is known to consist of a large group of nitrogenous compounds which are widely used as anesthetic, anticancer and central nervous stimulants. In addition to that, alkaloids are known to play some metabolic roles which include interference with cell division and antimicrobial properties [21], hence, the presence of alkaloid in the leaves extracts of Citrus aurantifolia could account for their use as antibacterial agent. According to the presence study, the plant leaves extracts demonstrated antibacterial efficacy against the test isolates. The findings showed that ethanol leaves extract exhibit higher activity than aqueous extract. The ethanolic leaves extract had highest zone of inhibition of $19.27 \mathrm{~mm}$ at
$100 \mathrm{mg} / \mathrm{ml}$ against Klebsiella while $17.89 \mathrm{~mm}$ for Escherichia coli while aqueous extract had highest zone of inhibition of $18.23 \mathrm{~mm}$ at the same concentration for Shigella while $16.41 \mathrm{~mm}$ against Escherichia coli at $100 \mathrm{mg} / \mathrm{ml}$. Higher activity of ethanol may be attributed to better solubility of the secondary metabolites in the ethanol extract which lead to better efficacy of the ethanol extract. However, Doughari et al. [25] stated that the anti-microbial effect of the plant could be due to the bioactive compounds such as the Phytochemicals constituent present in the plant. The finding of this study showed that the efficacy of Citrus aurantifolia leaves extracts on the test isolates had different hierarchy of susceptibility among the organisms. The findings of this study indicated that; higher concentration of the extract shows a greater zone of inhibition; this result agrees with that of Bisno and Stevens [26] which states that the higher the concentration of antibacterial substance, the higher it shows an appreciable zone of inhibition. The result of antibacterial activity of Citrus aurantifolia leaves extracts in the present study was in conformity with several studies conducted on the same extracts. Antibacterial assessment of Citrus aurantifolia aqueous ethanol, acetone, chloroform, ethanol and petroleum ether leaves 
extract conducted by Pathan R, et al. [14] against various pathogen showed significant activity against Staphylococcus aureus, Pseudomonas spp, Klebsiella pneumonia along with antifungal activity against Mucor spp., Aspergillus fumigates and Aspergillus niger. This is in conformity with the result of the present study. The finding of this study was also in conformity with that of Kandpal et al. [15] who isolated actinomycetes from C. aurantifolia and tested for antibacterial activity against various pathogens. In their study, five actinomycetes isolated from the plant exhibited antibacterial activity against various pathogens including S. aureus, E. coli, K. Pneumonia and S. typhi. Minimum inhibitory concentration of aqueous and ethanol extracts of Citrus aurantifolia leaves showed dilutions of various concentrations of aqueous and ethanol of the extracts can inhibit and/or kill the isolates. Lower MIC $(3.125 \mathrm{mg} /$ $\mathrm{ml}$ ) was shown by ethanol extract than aqueous extract. The ethanol extract exhibit MBC of between $12.5-50 \mathrm{mg} / \mathrm{ml}$.

\section{Conclusion}

Phytochemical screening of leaves extracts of Citrus aurantifolia indicated the presence of alkaloid, flavonoid, glycoside, saponin, steroid, phenols, terpenoid and tannin in both aqueous and ethanol extracts. The antibacterial efficacy of the extracts against the test isolates (S. typhi, E. coli, Klebsiella pneumoniae and Shigella) showed that the leaves extracts demonstrated an antimicrobial effect against the isolates. The Minimum inhibitory Concentration (MIC) of aqueous and ethanol extract showed dilutions of various concentrations of the extracts can inhibit and/or kill the isolates. The finding of this study supported the use of Citrus aurantifolia leaves extracts for medicinal purpose.

\section{Acknowledgement}

The authors wish to acknowledge to the staff of Microbiology Laboratory of Murtala Muhammad Specialist Hospital for provision of Samples. Thanks to the Management of Kano University of Science and Technology Wudil and School of Technology, Kano State Polytechnics for the use of laboratory facilities.

\section{References}

1. Sarker SD, Nahar L (2007) Chemistry for Pharmacy Students General, Organic and Natural Product Chemistry. John Wiley and Sons, England, pp. 283-359.

2. Igoli JO, Ogaji OG, Tor-anyiin AT, Igoli NP (2005) Traditional medicine practice amongst the Igede people of Nigeria part II. African Journal of Traditional, Complementary and Alternative Medicines 2(2): 134-152.

3. Cox S, Abu-Ghannam N, Gupta S (2010) An assessment of the antioxidant and antimicrobial activity of six species of edible Irish seaweeds. International Food Research Journal 17: 205-220.

4. World Health Organization (WHO) (2002) Use of anti-bacterial outside human medicine and result and antibacterial resistance in humans. World Health Organization.

5. Doughari JH (2004) Phytochemicals: Extraction Methods, Basic Structures and Mode of Action as Potential Chemotherapeutic Agents.
6. Tiwari R, Das K, Shrivastava DK (2010) Techniques for evaluation of medicinal plant products as antimicrobial agent: Current methods and future trends. Journal of Medicinal Plants Research 4: 104-111.

7. Leslie WR, Ellen RP, Banting DW, Fillery ED (2005) Longitudinal microbiological investigation of a hospitalized population of older adults with a high root surface caries risk. Journal of Dental Research 64: 1377-1381.

8. Odebiyi A, Sofowora AE (1978) Phytochemical Screening of Nigeria Medicinal plants. Part III Lloydia 41(3): 234-246.

9. Bakare AA, Bassey RB, Okoko IE, Sanyaolu AO, Ashamu AE, et al. (2012) Effect of Lime Juice (Citrus aurantifolia) on Histomorphological Alterations of the Ovaries and Uterus of Cyclic Sprague-Dawley Rats. European Journal of Scientific Research 67(4): 607-616.

10. Khan SRA (2005) Citrus quality to meet global demand. Int Food Res J 18: $1275-1282$.

11. Bina LJ, Tista P, Anjana, Kayo DY (2010) Study of antimicrobial activity of lime juice against Vibrio cholera. Scientific World 8: 44-48.

12. Tomotake H, Koga T, Yamato M, Kassu A, Ota F (2006) Antimicrobial activity of citrus fruits juices against Vibrio species. Iida Women's Junior College, Nagana, Japan, Nutritional Science Vitamin 52 (2): 157-160.

13. Khan PR, Gali PR, Pathan P, Gowthan T, Pasupuleti S (2012) In vitro antimicrobial activity of Citrus aurantifolia and its phytochemical screening. Live Sciences feed 1(2): 13 - 16.

14. Pathan RK, Gali PR, PathanP, Gowtham T, Pasupuleti S (2012) In vitro Antimicrobial Activity of Citrus aurantifolia and its Phytochemical Screening. Asian Pacific Journal of Tropical Disease S328-S331.

15. Kandpal KC, Jain DA, Kumar U, Rashmi Tripathi, Siva Kumar (2012) Isolation and Screening of Endophytic actinomycetes producing antibacterial compound from Citric aurantifolia fruit. European Journal of Experimental Biology 2(5): 1733-1737.

16. Holt JG, Krieg NR, Sneath PA, Stanley JT, Williams ST (1994) Bergeys manual of systematic bacteriology ( $9^{\text {th }}$ edn), Williams \& Wilkins Co, Baltimore, Maryland, USA, p.786.

17. Chessbrough M (2006) District laboratory practice in tropical countries, second edition, part two, Cambridge university press, London, UK.

18. Ali M, Yahaya A, Zage AU, Yusuf ZM (2017) In-vitro Antibacterial Activity and Phytochemical Screening of Psidium guajava on Some Enteric Bacterial Isolates of Public Health Importance. Journal of Advances in Medical and Pharmaceutical Sciences 12(3): 1-7.

19. Sofowora A (1993) Medicinal Plants and Traditional Medicine in Africa. ( $2^{\text {nd }}$ edn), Spectrum Books Ltd Ibadan Nigeria, p. 289.

20. Trease MT, Evans SE (1978) The phytochemical analysis and antibacterial screening of extracts of Tetracarpentum conophorum. J Chem Soc Nig 26: 57-58.

21. Nas FS, Oyeyi TI, Ali M (2018) Antibacterial efficacy and phytochemical screening of Senna siamea leaves extracts on some pathogenic bacteria. J Microbiol Exp 6(3): 159-163.

22. Madubunyi II (1995) Antimicrobial Activities of the Constituents of Garcinia kola seeds. Intern J Pharmacog 33: 232-237.

23. Gonzalez-Lamothe R, Mitchell G, Gattuso M, Diarra MS, Malouin F, et al. (2009) Plant antimicrobial agents and their effects on plant and human pathogens. J Mol Sci 10: 3400-3419.

24. Cowan MM (1999) Plants products as antimicrobial agents. Clin Microbiol Rev 12(4): 564-582.

25. Doughari JH, El-mahmod AM, Manzara S (2007) Studies on the antibacterial activity of root extracts of Carica papaya. L Afri J Microbiol Res 037- 041.

26. Bisno AL, Stevens DL (1996) Streptococcal infections of skin and soft tissues. New English Journal in Medicine 334: 240-245. 


\section{(c) (P) \\ This work is licensed under Creative Commons Attribution 4.0 License}

To Submit Your Article Click Here:

Submit Article

DOI: 10.32474/MAMS.2018.01.000107

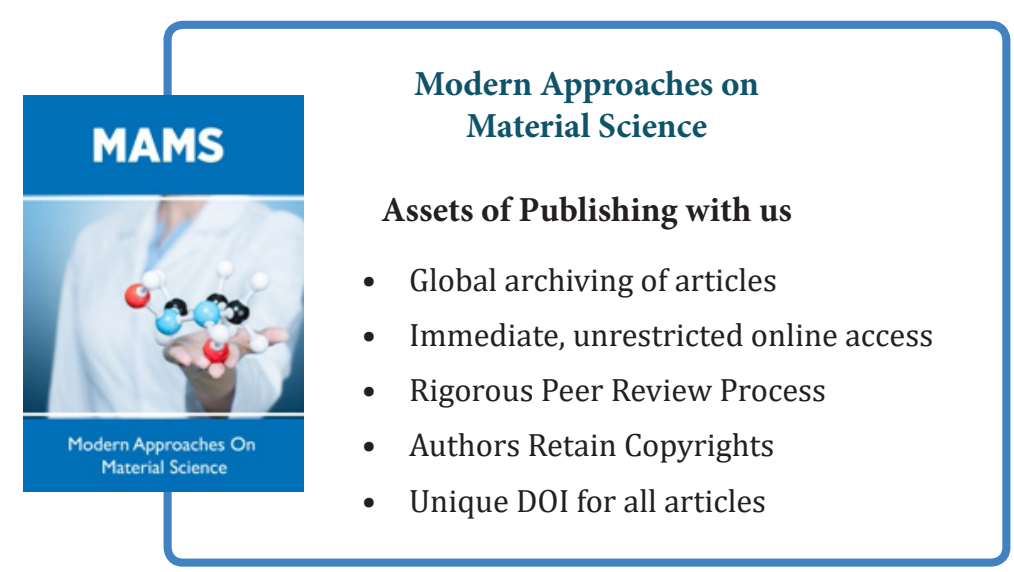

